\title{
The Influence of Customer Satisfaction on Financial Performance Through Customer Loyalty and Customer Advocacy: A Case Study of Indonesia's Local Brand
}

\section{Josua Tarigan and Saarce Elsye Hatane}

Faculty of Economics, Petra Christian University, Surabaya, East Java, Indonesia

\section{Abstract}

Free trade era makes every companies create and improve their excellence in order to compete with the competitors to attract customers' heart. Satisfaction and loyalty are powerful keys for the companies to survive because they are important indicators of the company's non-financial performance. Moreover, the level of customer advocacy also has a strong relationship with the financial performance. Advocacy itself is a special form of customer service where companies focus on what is best for the customers. The

Corresponding Author:

Josua Tarigan

josuat@petra.ac.id

Received: 29 January 2019 Accepted: 27 February 2019 Published: 24 March 2019

Publishing services provided by Knowledge E

(c) Josua Tarigan and Saarce Elsye Hatane. This article is distributed under the terms of the Creative Commons

Attribution License, which permits unrestricted use and redistribution provided that the original author and source are credited.

Selection and Peer-review under the responsibility of the $3 \mathrm{rd}$ ICEEBA Conference Committee. purpose of this research is to determine the impact of customer satisfaction to financial performance through customer loyalty and customer advocacy in various sectors companies in Indonesia. The samples are various sectors companies in Indonesia with criteria listed in the Indonesia Stock Exchange and its brand is registered in Indonesia Original Brands (IOB) in SWA magazine. The number of companies that fulfil the criteria are 13 companies with a four-year research period; therefore, the number of research sample is 52 firm-years. The analysis technique used Partial Least Square (PLS) approach. The results showed a positive impact of customer satisfaction to customer loyalty, customer advocacy, and financial performance. While customer loyalty and customer advocacy have no impact to financial performance, but customer loyalty has positive impact to customer advocacy.

Keywords: Indonesia original brands, customer satisfaction, customer loyalty, customer advocacy, financial performance

\section{Introduction}

Entering the globalization market in ASEAN, known as ASEAN Economy Community $(\mathrm{AEC})$, Indonesia has become the destination of many varieties of foreign brand since it was seen as a promising market. This was strengthened by the mind-set of the majority of the Indonesia people that has been contaminated with foreign brands. Therefore that each of entrepreneurs in Indonesia should be able to create and enhance the existing 
competitive advantage of their products or services. Literally, the local brand of Indonesia is not least when compared with foreign brands. Evidenced by some Indonesia's original brand that are well known to the world markets, such as Europe and America. Based on data from the Indonesian Textile Association (API), since 2014 every year Indonesia has recorded an export value for the local brand textiles amounted to US\$ 6 billion. This associate how local brands have been able to create customer satisfaction for local and foreign. Therefore, customer satisfaction and loyalty is one of the keys to success for the company to be able to survive in the era of globalization [1].

Reference [2] mentioned that non-financial performance such as customer loyalty and satisfaction are an important indicator of the company's performance. This is due to the existence of customer satisfaction and loyalty will influence on the financial performance of the company [3-5].

Reference $[2,6]$ explained more details that the customer satisfaction and loyalty is a non-financial performance predictor which used to measure the company's performance overall. While the customer advocacy is a form of a deeper relationship and specifically with customers through improving trust and higher commitment in both communications and collaboration [7]. Reference [8] also explains the urgency to select and embrace the customer as a company's representative to provide an open, honest and complete information. From the previous research conducted by [4] about the relationship of customer satisfaction, customer loyalty and customer advocacy against financial performance, discover the positive relationship between customer loyalties to the company profitability. Gupta and Reference [9] also showed that customer satisfaction is an early indicator and foremost to improve the company finance performance. Reference [10] says that customer loyalty can become a competitive advantage for the company to be able to push the performance of the company relative to competitors.

However, [11] also examined the impact of customer satisfaction on financial performance in the banking sector in Greece, showed that customer satisfaction was not shown to improve the bank's financial performance. The result of these studies showed inconsistencies in the results of the impact of customer satisfaction on financial performance. Therefore, customer satisfaction cannot be used as the sole factor in explaining the financial business performance increment. A business person also needs to see how the impact of customer loyalty into financial performance. This is supported from research conducted by [12] in the banking sector which shows that customer loyalty can influence financial performance.

Furthermore, [6] conducted a research on consumer one of the products of Starbucks, Chick-fil-A, Walmart, Whole Foods, Hobby Lobby and Nike. The result of these research 
which is also supported by [13] indicates that customer advocacy affects company financial performance through customer loyalty. Conversely, a research conducted by [14] states that customer advocacy toward a product or service can have a negative longterm relationship.

The existence of differences in the results of previous research in different countries related to customer satisfaction, customer loyalty, and customer advocacy, it triggers the researcher to further examine these variables in the Indonesia context, particularly related to Indonesia's original local brand. It is so important to contribute ideas over Indonesia's original local brand behavior to encounter AEC global competition.

\section{Literature Review and Hyphotesis}

\subsection{Customer satisfaction}

In the business, customer satisfaction is seen as one of the dimensions of financial performance. Increased of customer satisfaction will potentially lead to sales growth in the short and long term [15]. In otherwise customer dissatisfaction will bring a number of risks, such as the decrease in the level of sales, boycotts or protests from consumer organizations, government intervention, and the reaction of competitors and also the rise of new substitution products to the market. Reference [7] explained there are four methods that are widely used to measure the level of customer satisfaction, the complaints system and suggestion, ghost shopping, lost customer analysis and customer satisfaction surveys.

\subsection{Customer loyalty}

Reference [16] considered that customer loyalty can be measured from the tendency of consumer behaviour in making purchase, if consumers make repeat purchases of a product or service in the same place it has to be said as loyal customers, but if someone makes purchase only once within certain time then that person is considered as a not loyal customer. Reference [17] said that customer loyalty is can be created through service improvement to meet customer needs entirely.

According to [18], the customer can have the desire to buy more (willingness to pay more), or otherwise have a tendency to make the turn to other company (switching 
behavior). Reference [19] considered that a loyal customer has a high level of commitment, it makes consumers will continue to consume/use a product (willingness to pay more) and will not switch to another product (switching behavior).

\subsection{Customer advocacy}

Customer advocacy behavior concept more details compared to the concept of customer loyalty when associated with the management of the company's relationship with customers, because in addition to making a purchase and recommend it to other people. The customer who has the behavior of advocacy will be the defender and recommend the product/services they consume [8]. Reference [20] mentioned that Customer Advocacy is able to protect the company from negative word of mouth. According to [21], customer advocacy greatly encourage the company to creating a brand that is in demand by consumers. Advocacy is one of customer behavior/attitude to recommend to others in terms of product or service repurchase [22]. They are also explained the importance for companies to select and embrace the customer advocacy to be a loyal representation of the company. In this approach the company must provide an open, honest and absolute information to customers, due to the concept of advocacy reflect honesty and the fact is that customers know the realness of a product.

\subsection{Financial performance}

One of financial performance benchmark in a business organization is profitability. Profitability as the classic measurement used to know the organization performance. Generally, profitability ratios include return on assets, return on equity and net profit margin $[4,23]$.

\section{Net Profit Margin(NPM)}

Represented the size of the company's profitability from sales after deducting all costs and income taxes.

\section{Return on Asset (ROA)}

Represented the scale of net income of companies measured by asset value. This ratio shows the overall financial productivity of the company, both the loan capital, as well as its own. The higher the value of RO, the more effective the company manage its assets.

\section{Return on Equity (ROE)}


Shows the company's effectiveness in managing their own capital, measuring levels of investment profit that have done by the owner of capital or shareholders of the company. ROE indicates earnings ratios of the company, the greater the value of the ROE will be earning ratios of the company.

\subsection{The relationship of customer satisfaction and customer loyalty}

Customer loyalty is hard to be defended and it can be a point of reference of customer satisfaction in using a product or service from a company. Customers who are satisfied with a good or services, then it will often to use this product. This is the underlying customer loyalty will increase naturally due to the increasing of customer satisfaction $[12,24,25]$.

Reference [11] consider that customers who are satisfied with a product or service will be liable to recommend a product or service provider, otherwise if customers are not satisfied because of the poor quality of service or products offered, or any other factors, then they tend to switch to other service provider or products. Some of the things above which aspects influenced the following hypothesis:

$\mathrm{H}_{1}$ : There is influence of customer satisfaction toward customer loyalty

\subsection{Indonesia's original brands (IOB) index}

IOB is an index published in the SWA magazine, a prestigious business magazine in Indonesia. Every year the magazine publishes the IOB index, it has become a national reference of the original brand of Indonesia. The variables in this research that uses the index of the IOB variable, which are customer satisfaction, customer loyalty, and customer advocacy. IOB research involved 5241 respondents taken from six of a big city (area) in Indonesia, which are Jabodetabek, Medan, Bandung, Semarang, Surabaya and Makassar [26].

\subsection{The relationship of customer satisfaction and customer advocacy}

Reference [8] explain the customer satisfaction can be positioned at the base of the pyramid while advocating customers as the culmination of the pyramid. Customer satisfaction will foster a trust so that customer advocacy is formed by itself when the customer 
received satisfaction consistently. Reference [8] also reinforces that advocacy became one of the preferred strategy for enterprises to make customers are able to in control of the company. Reference [27] in her research shows customer satisfaction can increase customer advocacy significantly. Reference [28] mentioned that customer satisfaction is able to improve the perception of consumerism, it encourage them to promote it to others. Based on theory and the result of empirical research, it can be formulated as the following hypotheses:

$\mathrm{H}_{2}$ : There is influence of customer satisfaction toward customer advocacy

\subsection{The relationship between customer satisfaction and financial performance}

According to [29] utmost customer satisfaction lead to accelerated cash flow, sales volumes increment, as well as the reduction of the risk which related to the cash flow. Customer satisfaction lead to higher future revenue and reducing operational costs $[11,12,30,31]$. Satisfaction-profit-chain is a model which shows the relationship between customer satisfaction and financial performance [32]. This model considered that service performance will lead to increased customer satisfaction, which eventually produce a higher financial performance. Based on theory and the results of empirical research, it can be formulated as the following hypothesis:

$\mathrm{H}_{3}$ : There is an influence of customer satisfaction on financial performance

\subsection{The relationship between customer loyalty and customer advocacy}

Reference [24] describe a customer loyalty is understood as the desire of the customer to buy products and continue the relationship with the provider. Customer loyalty is very important because it has a positive impact on sales and customer retention, while advocacy is the customer desire to give a strong recommendation and praise for the manufacturer of a product or service to other customers. According to [33], customer loyalty is able to increase the commitment or the customer's trust with the services provided, so that they are easy to recommend to others. Consumer behavior theory asserts the existence of a difference between loyalty and advocacy, where customers are loyal not necessarily be advocacy, but customers who are truly loyal, likely to be 
advocacy. Susanta et al (2013) show that the customer loyalty recommended as predictors of customer advocacy on the product/service that exist. Based on the explanation above, hypothesis can be formulated as follows:

$\mathrm{H}_{4}$ : There is an influence of customer loyalty to customer advocacy

\subsection{The relationship customer loyalty and financial performance}

Reference [34] added that customer loyalty is the sign of the difference between a successful business and not. Customer loyalty gives a huge impact for the company, where the loyal customers would buy back the products/services the enjoy meaning before [29]. According to [35], customer loyalty is able to become a screening to the company's financial performance in the future. Reference [4] found a positive relationship between customer loyalty and financial performance in the banking sector in particular to the Return on Assets (ROA). Reference [4] found that increased one point in satisfaction (on a scale of 1-7) will increase by $0.59 \%$ ROA. Based on theoretical and empirical research, it can be formulated hypotheses as follows:

$\mathrm{H}_{5}$ : There is an influence of customer loyalty against financial performance

\subsection{The relationship between customer advocacy and financial performance}

Advocacy is the attitude of customers to give recommendations to the others in terms of purchase of a product of service. Reference [8] describes the behavior of a customer advocacy can lower the cost of new customer acquisition, as with advocacy, consumer trust against the company increased and companies can press charges for getting new customers. Reference [36] mentioned that higher consumer confidence will be closely linked to confidence in the company and the company's financial performance. Reference [8] also explained, advocacy became the foundation in maintaining sustainable competitive advantage, as the customer remained loyal to provide confidence to the company. Increased customer consumer due to the advocacy of customers will have an impact on the behavior of customers who will still be willing to pay higher although the company raised prices. The conditions will have an impact on increasing the profit margin obtained by the company. A larger profit margin will bring positive impact to the company's financial performance. Based on theory and the results of empirical research, it can be formulated as the following hypothesis: 
$\mathrm{H}_{6}$ : There is influence of customer advocacy toward financial performance

\section{Research Method}

This research tested the influence of customer satisfaction on financial performance through customer loyalty and customer advocacy. This research is quantitative research with secondary data. To test the hypothesis, this study using partial least square (PLS).

To test the hypothesis in this study used secondary data which the customer satisfaction, customer loyalty and customer advocacy data obtained from Indonesia Original Brand (IOB) which published in the business magazine SWA. While the financial performance (ROA, ROE, and NPM) using data from the financial reports of companies listed on the Indonesia Stock Exchange (BEI) year of 2011-2014.

The measurement scale used in this research is ratio scale. The sample selection technique used is the purposive sampling, where the samples will be selected based on specific criteria. Research criteria are as follows:

1. Number of companies according to the number brands registered in IOB (Indonesian Original Brands) in Mullen and survived during the years of 2011-2014. Brand source under the same company will be consider as one sample representative.

2. The company is registered as a public company on the Indonesia Stock Exchange between the years of 2011-2014.

3. The company publishes its annual financial reports periodically from the year of 2011-2014.

Based on above criteria, the following calculation results obtained:

TABLE 1: The Sample Determination.

Number of brands registered in IOB between $2011-2014$
(-) Number of company not listed in BEI
Brand registered in BEI
(-) Brand source under the same company
Number of company's total sample
(x) Observation period of 2011-2014
Number of observation

72 brands

51 brands

21 brands

8 brands

13 company

4 years

52 samples 


\section{Research Result and Discussions}

Total data used in this research are 52 samples (firm-years), which are consists of 13 companies with four years study period. To test the hypothesis of the study used analysis Partial Least Square (PLS) with SmartPLS program. The following is the first output from PLS analysis which is outer loading.

TABLE 2: The Value of Outer Loading.

Variable
Customer satisfaction
Customer loyalty
Customer advocacy
Financial performance

\begin{tabular}{|c|c|}
\hline Indicator & $\begin{array}{c}\text { Outer } \\
\text { Loading }\end{array}$ \\
\hline CSI & 1 \\
\hline CLI & 1 \\
\hline CAI & 1 \\
\hline ROA & 0.925 \\
\hline ROE & 0.867 \\
\hline NPM & 0.901 \\
\hline
\end{tabular}

Table 2 above shows the outer loading value of each indicator on variable customer satisfaction, customer loyalty, customer advocacy and financial performance, all of which have a value of more than 0.50 . This means that the indicators used in this research has met the convergent validity, and therefore could be used to create a model for research.

TABLE 3: Cross Loading Value.

Indicator
CSI
CLI
CAI
ROA
ROE
NPM

\begin{tabular}{|c|}
\hline $\begin{array}{c}\text { Customer } \\
\text { Satisfaction }\end{array}$ \\
\hline $\mathbf{1 . 0 0 0}$ \\
\hline 0.429 \\
\hline 0.618 \\
\hline 0.215 \\
\hline 0.188 \\
\hline 0.352 \\
\hline
\end{tabular}

\begin{tabular}{|c|}
\hline Customer Loyalty \\
\hline 0.429 \\
1.000 \\
0.724 \\
0.121 \\
0.108 \\
0.109 \\
\hline
\end{tabular}

\begin{tabular}{|c|}
\hline $\begin{array}{c}\text { Customer } \\
\text { Advocacy }\end{array}$ \\
\hline 0.618 \\
\hline 0.724 \\
\hline 1.000 \\
\hline 0.004 \\
\hline 0.026 \\
\hline 0.157 \\
\hline
\end{tabular}

\begin{tabular}{|c|}
\hline $\begin{array}{c}\text { Financial } \\
\text { Performance }\end{array}$ \\
\hline 0.305 \\
\hline 0.125 \\
\hline 0.092 \\
\hline $\mathbf{0 . 9 2 5}$ \\
\hline $\mathbf{0 . 8 6 7}$ \\
\hline $\mathbf{0 . 9 0 1}$ \\
\hline
\end{tabular}

Table 3 shows the value of the indicator variable cross loading all customer satisfaction, customer loyalty, customer advocacy and financial performance. From the value printed in bold can be seen that the value of cross loading has met the discriminant validity since the variable formed have the greatest value of the cross loading.

Table 4 above shown that each customer satisfaction variable, customer loyalty, customer advocacy and financial performance have the greater AVE roots value compare with the value of the correlation of other variables in the model, therefore it can be inferred that the variable customer satisfaction, customer loyalty, customer advocacy and financial performance has had good discriminant validity. 
TABLE 4: Discriminant Validity Tested with AVE Root.

\begin{tabular}{|l|c|c|c|c|c|c|c|}
\hline & AVE & $\begin{array}{l}\text { AVE } \\
\text { Voriable }\end{array}$ & & \multicolumn{3}{|c|}{ Correlation between Variable } \\
\hline & & & & CS & CL & CA & FP \\
\hline Customer satisfaction (CS) & 1 & 1 & CS & 1 & & \\
\hline Customer Loyalty (CL) & 1 & 1 & CL & 0,429 & 1 & \\
\hline Customer Advocacy (CA) & 1 & 1 & CA & 0,618 & 0,724 & 1 \\
\hline Financial Performance (FP) & 0,807 & 0,898 & FP & 0,305 & 0,125 & 0,092 & 1 \\
\hline
\end{tabular}

TABLE 5: Composite Reliability Value.

\begin{tabular}{l|c|}
\hline Variable & $\begin{array}{c}\text { Composite } \\
\text { Reliability }\end{array}$ \\
\hline Customer satisfaction & 1 \\
\hline Customer loyalty & 1 \\
\hline Customer advocacy & 1 \\
\hline Financial performance & 0.926 \\
\hline
\end{tabular}

Table 5 above indicated that the composite reliability value from each research variable has value more than 0,70 , therefore it can be concluded that each customer satisfaction variable, customer loyalty, customer advocacy, and financial performance have met the composite reliability.

TABLE 6: R-Square Value.

\begin{tabular}{l|c|}
\hline Variable & $R$-square \\
\hline Customer satisfaction & - \\
\hline Customer loyalty & 0.184 \\
\hline Customer advocacy & 0.639 \\
\hline Financial performance & 0.117
\end{tabular}

The value of R-Square for the customer loyalty variable is of 0,184 has the sense that percentage magnitude influence customer satisfaction toward customer loyalty is $18.4 \%$ while the rest is $81.6 \%$ explained by other variables. The R-Square value for customer advocacy is 0.639 have a sense that the magnitude of the influence of the percentage of customer satisfaction and customer loyalty toward the customer advocacy is 63.9\% while the rest of $36.1 \%$ explained by other variables. The value of R-Square for variable financial performance is 0,117 has the meaning that the percentage of the magnitude of the influence of customer satisfaction, customer loyalty and customer advocacy against financial performance is $11.7 \%$ while the rest is $88.3 \%$ explained by other variables. From the results can be concluded that the biggest predictor for customer loyalty is customer satisfaction. However both of the customer satisfaction and loyalty is only $11,7 \%$ influence 
the financial performance. It means, there are many variable that still can explain the financial performance for Indonesia Original Brands (IOB) context.

On the PLS model, assessment of goodness of fit is known from $Q^{2}$ value. $Q^{2}$ value had the same meaning as determination coefficient (R-Square) in the regression analysis, where the higher the $Q^{2}$, then the model can be said to be more fit with data. From the result of the calculation, it determined that $Q^{2}$ value size is 0,7402 , meanings a great diversity of research data can be explained by the structural model developed in this study is $74,02 \%$.

TABLE 7: Coefficient Path and $t$-statistics.

Pengaruh Antar Variable
Customer satisfaction $\rightarrow$ Customer loyalty
Customer satisfaction $\rightarrow$ Customer advocacy
Customer satisfaction $\rightarrow$ Financial Performance
Customer loyalty $\rightarrow$ Customer advocacy
Customer loyalty $\rightarrow$ Financial Performance
Customer advocacy $\rightarrow$ Financial Performance

\begin{tabular}{|c|}
\hline Original Sample \\
\hline 0.429 \\
\hline 0.377 \\
\hline 0.405 \\
\hline 0.562 \\
\hline 0.137 \\
\hline-0.257 \\
\hline
\end{tabular}

$T$ - Statistics 2.020 3.558 2.613 4.996 0.513 1.009

The value of customer satisfaction impact coefficient against customer loyalty is 0,429 with $t$-statistic 2,020 ( $>1$ 1.96). This indicates the existence of a positive and significant influence between the customer satisfaction toward customer loyalty, therefore the higher customer satisfaction on a product or service of the company, the customer will be more loyal toward a product or service from the company. Therefore, the first hypothesis suggested that customer satisfaction has an influence on customer loyalty, on the company's various sector in Indonesia can be supported.

The coefficient value of customer satisfaction impact to customer advocacy is 0,377 with t-statistic 3,558 (>1.96). This shows there is a positive and significant influence between the customer satisfactions against customer advocacy, the higher the customer satisfaction on product or services of the company, then the customer advocacy will higher toward the company's product or service, which is mean $\mathrm{H} 2$ is supported.

The coefficient impact value of customer satisfaction to financial performance is 0,405 with t-statistic 2,613 (> 1.96). This shows there is a positive and significant influence between customer satisfaction against financial performance, the higher the customer satisfaction on product or service of the company, it will increase the company financial performance, which is mean $\mathrm{H} 3$ is supported.

The value of the coefficient influencing customer loyalty toward the customer advocacy is 0,562 with $t$-statistic 4,996 (> 1.96). This shows there is a positive and significant influence on customer loyalty against customer advocacy, the higher customer loyalty 
over the company's product or service, then customer advocacy will be more increase in the company's product or service. Based on the results of the fourth hypothesis of the research presume that customer loyalty has an influence on customer advocacy at various company sectors in Indonesia are also supported.

The value of the coefficient influence customer loyalty toward financial performance is 0,137 with $t$-statistic $0,513(<1.96)$. This shows the influence of customer loyalty toward the financial performance is not significant, the higher customer loyalty over the products or services of the company, will have no significant impact in the real against the increase in the financial performance of the company, which is mean $\mathrm{H} 5$ is not supported. It can be inferred that customer loyalty requires providing the intervening variable impact on financial performance. Other analysis can also occur as revealed by

The company must be wise in giving loyalty programs against the customer, do not let this program impact reduces the company's financial performance, that resulted in an increase in sales that occur due to customer loyalty is not able to boost financial performance significantly because ultimately profit organization did not experience an increase [37].

The value of the coefficient influence customer advocacy toward financial performance is $-0,257$ with $t$-statistic $1,009(<1.96)$. This shows the influence of customer advocacy against financial performance is not significant, the higher the customer advocacy over the company product or service will not significant impact on the company's financial performance, which is mean $\mathrm{H} 6$ is not supported.

Silvestro (2007) considered that customer advocacy for products or services can affect sales in the short term, but in the long term, the program is able to improve customer advocacy sales, when balanced with the considerable cost, it will be less real impact toward the improvement of the company's financial performance.

\section{Conclusion and Recommendations}

This research uses customer satisfaction independent variable, while the customer loyalty and customer advocacy variable is the intervening variable. The dependent variable in this research is financial performance as measured used ROA, ROE, and NPM. Below is suggestion for companies and further research:

1. To maintain or even improve the performance of the finance, the company should more focus on a customer satisfaction, which already proven that customer satisfaction can improve the company's financial performance through customer loyalty. 
2. The company requires making an improvement in customer advocacy and customer loyalty with more efficiency in cost. Improvement program for loyalty and advocacy should be designed with minimal cost, in the term to increase in sales, as a result from the effective loyalty and program.

3. On the next researcher can add other intervening variables that also give an impact on financial performance, such as leadership, employee satisfaction etc. This research has its limitations since it uses only element of customer (satisfaction, loyalty and advocacy) as the predictor of profitability.

\section{References}

[1] Blocher, E., Stouth, D. E., Juras, P. E. et al. (2013). Cost Management: A Strategic Emphasis (sixth edition). NY: McGraw-Hill Company.

[2] Smith, R. E. and Wright, W. F. (2004). Determinants of customer loyalty and financial performance. Journal of Management Accounting Research, vol. 16, no. 1, pp. 183205.

[3] Lev, B. and Zarowin, P. (1999). The Boundaries of financial reporting and how to extend them (digest summary). Journal of Accounting Research, vol. 37, no. 2, pp. 353-385.

[4] Hallowell, R. (1996). The relationships of customer satisfaction, customer loyalty, and profitability: an empirical study. International Journal of Service Industry Management, vol. 7, no. 4, pp. 27-42.

[5] Storbacka, K., Strandvik, T., and Grönroos, C. (1994). Managing customer relationships for profit: the dynamics of relationship quality. International Journal of Service Industry Management, vol. 5, no. 5, pp. 21-38.

[6] Dodd, M. D. and Supa, D. W. (2014). Conceptualizing and measuring corporate social advocacy communication: Examining the impact on corporate financial performance. Public Relations Journal, vol. 8, no. 3.

[7] Kotler, P. and Keller, K. L. (2009). Marketing Management (twelfth edition). New Jersey: Pearson, Prentice Hall.

[8] Urban, G. L. (2005). Customer advocacy: A new era in marketing? Journal of Public Policy \& Marketing: May 2005, vol. 24, no. 1, pp. 155-159.

[9] Yavas, U. (2014). Correlates of customer loyalty to financial institutions: a case study. Journal of Consumer Marketing, vol. 31, no. 3, pp. 218-227.

[10] Ehigie, B. O. (2006). Correlates of customer loyalty to their bank: A Case study in Nigeria. International Journal of Bank Marketing, vol. 24, no. 7. 
[11] Keisidou, E., et al. (2013). Customer satisfaction, loyalty and financial performance: A holistic approach of the Greek banking sector. International Journal of Bank Marketing, vol. 31, no. 4, pp. 259-288.

[12] Nayebzadeh, S., Jalaly, M., and Shamsi, H. M. (2013). The relationship between customer satisfaction and loyalty with the bank performance in Iran. International Journal of Academic Research in Business and Social Sciences, vol. 3, no. 6, p. 114.

[13] Lacey, R. and Morgan, R. M. (2009). Customer advocacy and the impact of B2B loyalty programs. Journal of Business \& Industrial Marketing, vol. 24/1, pp. 3-13.

[14] Silvestro. (2007). The assymmetric relationship between customer satisfaction, dissatisfaction, loyalty and financial performance in b2b companies. The Researchgate Article. Retrieved from: https://www.researchgate.net/publication/242204511 (accessed March 17, 2016).

[15] Kim, G. (2007). The Service recovery strategies, customer satisfaction, customer loyalty. Asian Journal of Quality, vol. 8, no. 1, pp. 76-86.

[16] Griffin, J. (1999). Customer loyalty development evolves in stages. Austin Business Journal, vol. 1-3. Retrieved from: http://www.bizjournals.com (accessed on October 20, 2015).

[17] Kursunlouglu, E. (2014). Shopping centre customer service: Creating customer satisfaction and loyalty. Marketing Intelligence and Planning, vol. 32, no. 4.

[18] Yu, Y. T. and Dean, A. (2001). The contribution of emotional satisfaction to consumer loyalty. International Journal of Service Industry Management, vol. 12, no. 3, pp. 234250.

[19] Oliver, R. L. (1999). Whence customer loyalty. Journal of Marketing, vol. 63, pp. 33-44.

[20] Chelminski, P. and Coulter, R. (2011). An examination of customer advocacy and complaining behavior in the context of service failure. Journal of Service Marketing, vol. 25 , no. 5.

[21] Lawer, C. and Knox, S. (2006). Customer advocacy and brand development. Journal of Product and Brand Management, vol. 15, no. 2, pp. 121-129.

[22] Fullerton, G. and Taylor, S. (2000). The Role of Commitment in Service Relationship. Ontario: School of Business Acadia University (limited publication).

[23] Ross, S. A., Westerfield, R. W., and Jordan, B. D. (2003). Fundamental of Corporate Finance (sixth edition). Singapore: McGraw-Hill Book Company.

[24] Susanta, et al. (2013). The effect of relationship quality on customer advocacy: the mediating role of loyalty. Journal of Business and Management, vol. 10, no. 4, pp. $41-52$. 
[25] Pollack, B. L. (2009). Linking the hierarchical service quality model to customer satisfaction and loyalty. Journal of Services Marketing, vol. 23, no. 1, pp. 42-50.

[26] Top 250: Indonesia Original Brands 2014, SWA Magazine, Issue 16, 2014.

[27] Hidayah, N. (2012). Pengaruh nilai pelanggan dan kepuasan pelanggan terhadap perilaku advokasi pelanggan. Jurnal IImiah Pariwisata, vol. 7J, pp. 170-192.

[28] Loughman, T. P. (2009). The effect of physicians communication satisfaction and their perceptions of empowerment on their likelihood to recommend a hospital to their peers: A mixed method study. Management Research News, vol. 32, no. 4, pp. 354370.

[29] Gupta, S. and Zeithaml, V. (2006). Customer metrics and their impact on financial performance. Marketing Science Journal, vol. 25, no. 6, pp. 718-739.

[30] Eren, S. S., et al. (2013). The effect of service orientation on financial performance: The mediating role of job satisfaction and customer satisfaction. Procedia-Social and Behavioral Sciences, vol. 99, pp. 665-672.

[31] Al-Hawari, M. and Ward, T. (2006). The effect of automated service quality on Australian banks' financial performance and the mediating role of customer satisfaction. Marketing Intelligence \& Planning, vol. 24, no. 2.

[32] Anderson, E. W. and Mittal, V. (2000). Strengthening the satisfaction-profit chain. Journal of Service Research, vol. 3, no. 2, pp. 107-120.

[33] Liang, C. (2009). The influence of customer perceptions on financial performance in financial services. International Journal of Bank Marketing, vol. 27, no. 2.

[34] Mullen, A. J. (2007). Customer loyalty means greater profitability. Proquest, vol. 56, no. 9, p. 66. Retrieved from: http://www.Itlmagazine.com/article/customer-loyaltymeans-greater-profi-tability (accessed on November 29, 2015).

[35] Williams, P. and Nauman, E. (2011). Customer satisfaction and business performance: A firm-level analysis. Journal of Service Marketing, vol. 25, no.1, pp. 20-32.

[36] Heffernan, T. (2008). The impact of emotional intelligence and trust on bank performance. International Journal of Bank Marketing, vol. 26, no. 3.

[37] Simon, H., Bilstein, F. F., and Luby, F. (2006). Manage for profit, not for market share: A guide to greater profits in highly contested markets. Harvard Business Review Press. 